\title{
OWADY NORWIDA \\ OSTATNIA Z BAJEK, CZYLI O PIĘKNOŚCI ISTNIENIA
}

\begin{abstract}
Alem był na przedmieściach w Jego Jeruzalem:
W wodzie obłoków krzyżem pławiąc się czerwonym,

Zwierzo-krzewowe psalmy mówiłem z koralem,

$\mathrm{Z}$ delfinem - pacierz, $\mathrm{z}$ orłem - g 1 o r i e - uskrzydlonym.

(PWsz II, 155)
\end{abstract}

\section{ISTNIENIE JAKO MIEJSCE WSPÓLNE}

W romantyzmie historia naturalna leży u podstaw nie tylko wykształcenia, ale także dociekań epoki, stanowi jej głęboki nurt. Zofia Stefanowska w studium Świat owadzi w czwartej części „Dziadów”" zwróciła uwagę na rangę tego aspektu badań naukowych oraz zainicjowała ich tradycję.

Myśl Cypriana Norwida o mowie zwierząt i randze ich istnienia (współistnienia wraz z człowiekiem) wyrażona została chociażby w późnych utworach poety należących do dzieł pośmiertnych (opera posthuma) romantyzmu ${ }^{2}$, m.in. w Ostatniej z bajek (powst. $1882^{3}$ ) oraz w studium o charakterze eseistycznym

${ }^{1}$ Z. Stefanowska, Świat owadzi w czwartej czéści „Dziadów”, w: Studia romantyczne, prace pod red. Marii Żmigrodzkiej poświęcone VII Międzynarodowemu Kongresowi Slawistów, Wrocław 1973, s. 289-312; studium weszło do zbioru prac Zofii Stefanowskiej Próba zdrowego rozumu. Studia o Mickiewiczu (Warszawa 1976).

2 Na temat specyfiki twórczości publikowanej po śmierci poetów pisałam w książce Romantyzm ,brulionowy”, Warszawa 2015.

3 Datę tę przyjąć należy za umowną. Pierwodruk pośmiertny „Chimera” 1902, t. VI, z. 18. Zob. Ostatnia z bajek - Uwagi edytorskie, w: DW VII, 366-368. 
pt. Fabulizm Darwina (powst. $1882^{4}$ ). Wyrasta ona z ducha epoki romantyzmu, a także z dyskusji na temat historii naturalnej, jakie były kontynuowane zarówno w pierwszej jak i w drugiej połowie wieku dziewiętnastego.

Ów stosunek człowieka-słuchacza do przyrody, w tym do wszystkich istot żywych (nawet tych najdrobniejszych) oraz równie ważna - relacja świata zwierzęcego wobec człowieka składa się na pewną integralną całość. Udzielenie przez Norwida głosu zwierzętom - „braciom mniejszym” (określenie przypisywane świętemu Franciszkowi nie jest tu bezzasadne ${ }^{5}$ ) oddaje istotę przeżyć w świecie natury; przeżyć, które nie są od ludzkich gorsze lub odbiegające jakością, choć oczywiście inne - związane z rozwojem i miejscem zaistnienia w historii naturalnej. W świecie wspomnianych utworów Norwida człowiek wydaje się kimś zewnętrznym wobec świata przyrody, kimś, kto przestał słuchać i słyszeć ów głos innych istot, utracił zatem naturalną, a także nadprzyrodzoną więź ze światem, mimo że od początku był zatopiony w świecie natury - przestał ów świat pojmować.

Pełnia porozumienia człowieka ze światem przyrody została oddana przez Adama Mickiewicza w Panu Tadeuszu. Poeta jest doskonałym słuchaczem i thumaczem mowy zwierząt, roślin oraz zjawisk przyrodniczych. W poemacie istoty żywe w określony sposób komunikują się, posiadają zdolność doświadczania uczuć. Jest to istotny aspekt, który pozwala dopełnić znaczenie romantycznej kategorii „piękności” (na którą poeta wskazuje już w inwokacji do poematu). Jej źródłem są istniejące w naturze związki i wzajemne relacje łączące człowieka z samym źródłem istnienia. Norwid podejmuje w Ostatniej z bajek kwestię sposobów rozumienia „piękności” (to temat niezwykle ważny dla epoki), poeta miał bowiem świadomość istotnych zmian cywilizacyjnych i kulturowych, a tym samym oddalenia się człowieka od czystego źródła natury, zerwania więzów. Baśniowość poematu Mickiewicza wydobyła cudowność świata natury, której źródłem stał się niezwykły świat przyrody oraz związek, jaki łączył człowieka z pozostałymi istotami żyjącymi na wspólnej dla nich ziemi. W Ostatniej z bajek człowiek nie potrafi już czytać znaków natury, pozbawił się czegoś niezwykle ważnego, życiodajnego doświadczenia piękności istnienia w całej jej rozmaitości.

Historia naturalna spotyka się z literaturą, obecna jest w osiemnasto- i dziewiętnastowiecznym systemie kształcenia (w gimnazjach i na uniwersytetach jest

${ }^{4}$ Datę powstania Fabulizmu Darwina należy przyjąć za umowną. Pierwodruk: Wszystkie pisma Cypriana Norwida. Wydanie i naktad Z. Przesmyckiego, t. VII: Pisma filozoficzne, społeczne itd., Warszawa 1939. Zob. Dzieje edytorskie, w: PWsz VII, 508 i in.

${ }^{5} \mathrm{O}$ wpływie duchowości franciszkańskiej na Norwida pisała m.in. G. HALKIEwICz-SoJAK, Wobec tajemnicy i prawdy. O Norwidowskich obrazach ,całości”, Toruń 1998 (fragment książki zatytułowany: W koncepcji antropologicznej ,,Ostatniej z bajek”), s. 212. 
przedmiotem ważnym i podstawowym). Wystarczy wspomnieć solidny kurs historii naturalnej, jaki odbył Norwid w gimnazjum warszawskim pod kierunkiem uczonego: Antoniego Wagi, z którym poeta utrzymywał znajomość w zasadzie do końca życia.

Ostatnia z bajek należy do utworów bardzo ważnych, jeśli chodzi o Norwidowską koncepcję człowieka oraz ugruntowaną w badaniach nad twórczością poety wizję osoby jako pielgrzyma będącego w ciągłej drodze do Boga, w pełni świadomego rangi zbawienia i celu finalnego swej wędrówki. Rozbudowana przypowieść Norwida odsłania obraz człowieka jako istoty stworzonej przez Boga, ale pośród innych istot stworzonych, nie gorszych i nie mniej ważnych od niego, ponieważ również - tak jak człowiek - będących dziełami Stwórcy. Wątek pielgrzymi jest obecny w badaniach nad twórczością poety. W późnej twórczości Norwida (do takiej należy zaliczyć Ostatnia z bajek) miarą człowieczeństwa wydaje się nie tylko pielgrzymstwo, ,zapewnione” w osobie Chrystusa odkupienie, które się w dziejach dokonało i dokonuje, nieustanna praca, wysiłek budowania w sobie najwyższych wartości (tak wiele w tym temacie już ustalono), ale także wpisany w trud istnienia stosunek człowieka wobec innych istot żywych, tak jak on powołanych do życia w procesie genesis. Miarą człowieczeństwa we wspomnianym dziele Norwida jest współistnienie, a więc relacja człowieka nie tylko z inną osobą, ale szerzej - z innym istnieniem. Posiadanie życia - to miejsce wspólne dla wszystkich istot żywych na ziemi.

\section{2. „W OGROJCU ROŚLIN I ZWIERZĄT”}

Anioł - bohater Ostatniej z bajek roztacza pochwalną pieśń nad kołyską nowo narodzonego dziecka wzywając świat owadzi i „zwierzątek” (jak to zdrobniale określa) do swego rodzaju adoracji życia człowieka:

„Wy! Pokwapcie się, lekkie, składne, jasne motyle, i wy, muszki drobne, zlote jak iskry. Wy, ptaszki wesołe, i wy, zwinne polne i leśne zwierzątka... Wszystek ten drobny świat, który jakoby zabawkami dla kogoś doskonalszego jest nastręczonym, niech się on kwapi dziś, gdyż oto dni temu nieco - najpiękniejsze ze stworzeń, człowiek przyszedł na świat!" (DW VII, 242, podkr. E. Sz.-P.)

Dziecko owinięte w pieluszki, niesione do chrztu przywołuje obrazy niewinności i czystości. Jednakże ta uroczysta pieśń pochwalna nieco zagadkowego Anioła, który w godzinie południowej „leci ponad siołem”, znajduje odpowiedź w świecie przyrody. Status Anioła Stróża jest niejasny, wydaje się on być bardzo odle- 
głym gościem, który ledwo zdążył przylecieć na ziemię, ponieważ narodziło się dziecię i ma nad nim piastować opiekę. Niewiele jednak wie o życiu „na ziemi”. Nie ma w nim - co należy podkreślić - powagi aniołów biblijnych. Zgodnie z tradycją Anioł Stróż przybywał na ziemię z niebios w momencie narodzin dziecka, by się nim opiekować. ${ }^{6} \mathrm{~W}$ Ostatniej z bajek przypomina on bardziej wizerunki $\mathrm{z}$ niezwykle popularnych i rozpowszechnianych w wieku dziewiętnastym, przepełnionych naiwnością obrazków przedstawiających Anioła Stróża prowadzącego dzieci przez most lub otaczającego ich opieką, chroniącego przed niebezpieczeństwami, podczas gdy bawią się nad rzeką. Tego rodzaju obrazki (popularne również współcześnie) stanowiły częstokroć podarunek z okazji przyjęcia sakramentu chrztu. Największą uwagę na tego rodzaju dewocjonaliach zwracają anioły, są one duże, piękne i często bez aureoli, czasami z jasną gwiazdą nad głową oraz wizerunki przedstawianych na tych obrazkach dzieci, otóż zwykle chłopiec goni za motylkiem, a dziewczynka ma w rękach zerwane kwiaty. Obrazek odbierany jest jako sielankowy, idylliczny wręcz, bo przecież niebezpieczeństwa, które czyhają na dzieci zostaną przez Anioła Stróża przewidziane, a dzieci - ochronione; nie wpadną do strumienia, nie spadną w przepaść. Owady i kwiaty odciągają uwagę dzieci od potencjalnych niebezpieczeństw. ${ }^{7}$ Kolorystyka przedstawień, ich „słoneczność”, ckliwe postaci „pięknych” dzieci (chłopczyka i dziewczynki), raczej wysoko urodzonych, o czym świadczy ich ubiór, mają „,ieszyć serce”. Ten religijny obrazek ma w prosty sposób tłumaczyć obecność nieziemskiego, baśniowego wręcz, czuwającego Anioła. Nie razi nikogo, że dziewczynka zrywa dla zabawy

${ }^{6}$ Zob. M. BARANowsKa, Aniot [hasło], w: Stownik literatury polskiej XIX wieku, red. J. Bachórz, A. Kowalczykowa, Wrocław 2009, s. 26-28; Księga o Aniołach, red. H. Oleschko, Kraków 2002; R. Otsason, Anioł [hasło], w: Powszechna Encyklopedia Filozofii, Lublin 2000, t. 1, s. 234-235; D. Szagun, Aniot i anielskość w romantyzmie na podstawie poezji Kornela Ujejskiego $i$ Cypriana Norwida, w: Anioł w literaturze i w kulturze, red. J. Łagowska, J. Skawiński, Wrocław 2004, t. 1; I. WaKSMUnDZKA, Anioł u Norwida, „Colloquia Litteraria” 2017, nr 1.

${ }^{7}$ Potwierdzeniem niezwykłej popularności obrazków z Aniołem Stróżem jest także religijna literatura popularna epoki, np. Pamiętniki Anioła Stróża przez księdza Chardou, Pelplin 1872. Zacytuję znaczący fragment:

„Mój mały braciszek biegał po łące: byłem z nim i śledziłem każde poruszenie jego.

Owad wyssawszy z rośliny truciznę zaczął latać koło niego. - Dziecię chciało go przyciągnąć i schwytać... jednem / tchnieniem go odpędziłem i wybawiłem braciszka mojego.

Pośród zieleni pełzał gad zatruty. - Oko pełne ognia. Zmierzając żądło chciał się cisnąć na dziecinę. Końcem swego skrzydła spędziłem z łona róży ładnego motyla, dziecię pobiegło za nim i umknęło od gadziny.

Nie tylko podobne wypadki codzienne wymagały mej pomocy, były i takie, co potrzebowały wsparcia widomego". (Tamże, s. 23). 
kwiaty, być może rzuci je za chwilę gdzieś na bok, a chłopiec goni owady, a co się stanie, jeśli je złapie? Drobna istota ludzka łapie drobne owady - zachodzi tu analogia i dominuje proporcja. Owadzi, mały świat odpowiada dziecięcemu mikrokosmosowi. Na tych przepełnionych naiwnością obrazkach, których produkcja piętrzyła się w XIX wieku (o tym świadczy prasa), chłopczyk jawi się jako mały łowca, który już za kilka, kilkanaście lat sportretowany zostanie jako myśliwy lub oficer, dziewczynka jako piękny, rozwijający się kwiat, wkrótce kobieta.

Poeta romantyczny (Norwid) widzi jednak więcej. Na tym obrazku (czy może lepiej powiedzieć w tym idyllicznym obrazie świata, którego częścią staje się Anioł) dostrzega potencjalną, okrutną ingerencję małego chłopca w mały (per analogiam) świat owadzi. Czyż świat może jakąś szkodę ponieść, gdy dla zabawy ginie motyl? Nawet Anioł z dziewiętnastowiecznego obrazka nie zwraca na to uwagi, ze spokojem, pobłażliwym, w pełni akceptującym uśmiechem i pogodnym obliczem nie wstrzymuje ręki chłopca, by odsłonić przed nim sens istnienia motyla, troszczy się i osłania dziecko przed niebezpieczeństwem utopienia się, zboczenia z drogi, zrobienia sobie krzywdy. Życie małej istoty ludzkiej jest najważniejsze. Gonione owady i zerwane kwiaty - nie mają tu większego znaczenia, nie pochłaniają uwagi obserwatora. Być może odbiorca odczytuje tę scenę odwołując się np. do rozumienia motyla jako znaku chwilowej zabawy, beztroskiej radości (tak jak np. obraz Zosi, która próbuje dogonić baranka i złapać motylka - w II cz. Dziadów, ponieważ - według słów Guślarza - dziewczyna „nie dotknęła ziemi ni razu").

Nie ma jednak w „treści” dziewiętnastowiecznych obrazków upomnienia, sugestii, wątpliwości czy chłopiec może motylka złapać, czy może się nim bawić. W słodkiej krainie interpretującej w naiwny (choć częstokroć bliski sercu) sposób idyllę, obserwator zatrzymuje się tylko na danym (przedstawionym) fragmencie świata. Omawiane i popularne w epoce obrazki z pewnością nie były obce Norwidowi, świadczą o tym rysunki poety: Anioł Stróż, data powst. 1873, tusz-pióro, w zasobach Biblioteki Narodowej ${ }^{8} \mathrm{w}$ Warszawie czy uznana za zaginioną akwarela Dziecko i Anioł znana z reprodukcji z 1933 roku. O popularności i randze Bożego opiekuna człowieka świadczą także popularne w XIX wieku modlitewniki tytułowane jako np. Anioł Stróż: skarbczyk modlitewny dla młodzieży i dzieci ptci

${ }^{8}$ Zob. E. ChlebowsKa, Cyprian Norwid. Katalog prac plastycznych, t. IV: Prace luźne 2, Lublin 2019, s. 264. W tym miejscu pragnę najserdeczniej podziękować Autorce Katalogu za wszelką pomoc, życzliwość i udostępnienie mi materiałów na temat powyższego rysunku oraz wspomnianej w dalszej części artykuł akwareli pt. Anioł i dziecko. Rysunek Anioł Stróż znajduje się w cyfrowych zasobach Biblioteki Narodowej (Polona). 
obojga ${ }^{9}$.W tego rodzaju książeczkach znajdowały się wszelkie modlitwy, pieśni, przykazania, na czele z modlitwą, którą jako pierwszą poznają zwykle małe już dzieci, czyli Oratio ad Angelum Custodem:

\begin{abstract}
Angele Dei, qui custos es mei, me, tibicommissumpietatesuperna, illumina, custodi, rege et guberna. Amen.
\end{abstract}

Wspomniane modlitewniki dla dzieci i młodzieży zawierały często ilustrację przedstawiającą dziecko i kroczącego za nim, czuwającego Anioła

Anioł z pierwszych partii Ostatniej z bajek składa się na „idylliczny” dziewiętnastowieczny obrazek wzywając świat owadzi, ptasi i drobnych zwierząt do hymnu pochwalnego na cześć nowonarodzonego dziecka. Ów świat jest jednak z niezwykłą delikatnością przez poetę opisany, dlatego zwraca na siebie uwagę czytelnika w znacznie większym stopniu niż sam Anioł i każe zapytać o status tego mikroświata: motyle Norwida są jasne i „,składne”, muszki - „złote jak iskry”, „ptaszki wesołe”. Anioł jednak obwieszcza: „Wszystek ten drobny świat, który jakoby zabawkami dla kogoś doskonalszego jest nastręczonym [...].” Słowa wydają się wręcz kluczowe: opisana przez poetę z niemałą wzniosłością i szlachetnością rodzina owadów, ptaków, mniejszych i większych zwierząt to - według słów Anioła - tylko „zabawka dla kogoś doskonalszego”. Jeśli nawet spróbujemy przyjąć - bardzo powierzchownie, na próbę - że człowiek jest „kimś doskonalszym", to Norwid nie przystałby na to, aby jakakolwiek istota miałaby stać się dla drugiej zabawką np. zwierzę dla człowieka. Norwid - romantyczny „Z ducha” poeta nie mógłby takiej tezy uznać i przyjąć. Znalazło to częściowo odzwierciedlenie w badaniach nad Ostatnia z bajek i stosunkiem Norwida do zwierząt (Janina Abramowska, Grażyna Halkiewicz-Sojak, Piotr Lehr-Sławiński, Magdalena Rudkowska $\left.{ }^{10}\right)$. Fakt, że inne od człowieka istoty żywe są dziełem

${ }^{9}$ Zob. Aniol Stróż: skarbczyk modlitewny dla młodzieży i dzieci płci obojga, [Częstochowa] 1933, Biblioteka Narodowa (bn.org.pl), Polona.

${ }^{10}$ Zob. P. LeHr-SPŁawiŃSki, Darwin - Narwid - Norwid, w: Dziewiętnastowieczność, red. E. Czaplejewicz, W. Grajewski, Wrocław-Warszawa 1988; J. AвRAmowska, Darwin, Ezop i Aniot, w: Nie tylko o Norwidzie, red. J. Czarnomorska, Z. Przychodniak, K. Trybuś, Poznań 1997 (do tematyki Ostatniej z bajek Janina ABRAMOwsKa powróciła w swojej książce: Pisarze w zwierzyńcu, Poznań 2010, s. 40-42); M. RudKowsKa, Ostatnie z bajek. Romantyczna iluzja wspólnoty ludzko-zwierzęcej i jej rozpad, „Wiek XIX. Rocznik Towarzystwa Literackiego im. Adama Mickiewicza", 2014. Z tezami Piotra Lehra-Spławińskiego polemizowała Alina Merdas uznając za główną ideę Ostatniej z bajek, „prawdę o człowieku potrzebującym odkupienia”: A. MERDAS RSCJ, Oca- 
Stwórcy, czyli są stworzeniami - jest dla Norwida wystarczającą przesłanką, aby okazać im należyty szacunek i podziw. Pogląd Norwida na status istnienia zwierząt wyraźnie brzmi zarówno w Ostatniej z bajek jak i w Fabulizmie Darwina oraz chociażby w korespondencji, np. w tych fragmentach, kiedy mowa jest o ogrodach zoologicznych - obiektach nie do zaakceptowania przez Norwida. Dowodem na to jest m.in. korespondencja z Seweryną Duchińską (autorką felietonów poświęconych rozwojowi historii naturalnej i popularnej w epoce teorii Karola Darwina $^{11}$ ). Za niezwykle znaczące uznać należy pojawiające się w liście Norwida (z 1879) roku do Duchińskiej określenie ogrodu zoologicznego jako: „Ogrojca roślin i zwierząt":

Podobno, że Łaskawa Pani, będąc w progach tych tu murów, raczyła o mnie zapytywać - otóż właśnie że wyszedłem do Ogrojca roślin i zwierząt [...]. Spółcześni tłumnie biegną do Ogrodu-aklimatyzacji [...] ażeby widzieć ich (wedle Darwina) przodka orangutanga, a nie pojmuję u tych osób podzielających system naturalisty angielskiego, dlaczego one antenata w klatce z małpami osadziły i parasolkami przez kratę do niego bodzą ?... Obyczaj, którego żaden ze współwyznawców moich nie dopuściłby się względem portretu dziada swego! - Orangutatang też z politowaniem i newralgią na tę z d z i c z a ł ą - c y w i 1 i z a c j ą rzeszę poogląda... W tym to jednym pokrewnym mu jestem $[\ldots]^{12}$.

Jest to ważny cytat. Jeśli nawet Norwid nie zaakceptował teorii Darwina, to ogrody (,ogrojce”) zoologiczne uznał za wypaczenie cywilizacyjne, a zachowanie ludzi wobec zwierząt - za skandaliczne. Dodajmy, że poeta odsłonił sytuację dwukierunkowej obserwacji, pokazał ją nie tylko z ludzkiej, ale także zwierzęcej perspektywy (podobnie jak w Ostatniej z bajek). W cytowanym fragmencie listu

lony wieniec, Warszawa 1995, s. 209. Za istotny w świetle historii interpretacji Ostatniej z bajek uznać należy m.in. studium Elżbiety FELIKSIAK, Darwin Norwida, „Teksty” 1972, nr 4 oraz Grażyny HalkiewICZ-SoJak, Wobec tajemnicy i prawdy. O Norwidowskich obrazach „,całości” (fragment książki zatytułowany: W koncepcji antropologicznej „Ostatniej z bajek”).

${ }^{11}$ Zob. S. DuchińsKA, Kronika Paryzka, „Biblioteka Warszawska” 1864, t. 3. Felietony Duchińskiej nie byłe w epoce oceniane wysoko, ale uznano je za ważne. B. Rejchman pisał na ten temat: „Autorka lekkich felietonów pt. »Kronika Paryska« w »Bibliotece Warszawskiej« była pierwszym zwiastunem nowej epoki w nauce, podając we wrześniu roku 1864 wiadomość o poglądach d'Archiaca, w świeżo wyszłym tomie Kursu Paleontologii i Flourensa w »examem du livre de M. Darwin« - na nową teorię ewolucji”. Dodaje jednak, że Duchińska „nie dobrze rozumiała o czym pisze". B. Rejchman, Teoria Darwina w stosunku do nauki życia, Warszawa 1882, s. 11. Cyt. za: R. KozıoŁeK, Kompleks Darwina, „Teksty Drugie” 2011, z. 3, s. 16 (przypis 16).

${ }^{12}$ C. NorwID, List do Seweryny Duchińskiej, PW X, 130, 131. Wielu badaczy podkreśla znaczenie tego listu dla powstania Ostatniej z bajek. Zob. J. W. GomULICKI, Metryki i objaśnienia: „, Ostatnia z bajek”, PWsz VII, cz. II; P. LeHR-SPŁawIŃSKI, Darwin-Narwid - Norwid; G. HaLKIEWICZ-SOJAK, Wobec tajemnicy i prawdy. 
do Duchińskiej - orangutan ,z politowaniem i newralgią” patrzy na ludzi i „cywilizację zdziczałą”. Zdziczałe zatem przestały być zwierzęta. Myśl pisarza wyrażona w liście pozwala zrozumieć Ostatnia z bajek. Przy okazji należy dodać, że w dziewiętnastowiecznych ogrodach zoologicznych (np. w Amsterdamie) zamykani byli ludzie np. z plemion kongijskich, co dobitnie potwierdza ową „zdziczałość cywilizacyjną". ${ }^{13}$

\section{O IDYLLI, CZYLI ILUZJI PIĘKNA}

W utworze Norwida tak jak w bajkach głosu użyczono zwierzętom: Aniołowi (na wezwanie do hymnu pochwalnego) odpowiadają owady, rozpoczyna je jednak preludium ciszy i opis ujawniający piękno niewielkich rozmiarów stworzeń:

Tak gdy swoją pieśn skończył Anioł, nastąpiła na bardzo mało chwila głębokiego uciszenia, po czym jak jednej struny złotej wygłos zabrzmiały słowa drobnych zlotych muszek i owadków tęczowych, i motyli w pyły świetne owianych. (DW VII, 243)

Opisy świata zwierzęcego w Ostatniej z bajek są nobilitujące, pochwalne wręcz. Swego rodzaju liryczny hymn na cześć owadów wypowiedziany przez poetę jest doskonalszy od hymnu anielskiego wygłoszonego na cześć istoty ludzkiej. „Złote muszki”, „tęczowe owadki”, w innym miejscu tekstu nazywane „tęczowymi robaczkami”"14 , motyle - „W pyły świetne owiane” ${ }^{15}$ są częścią dość sła-

${ }^{13}$ Zob. m. in.: M. KLusZCZYŃsKA, Ogród zoologiczny jako miejsce konstruowania Zwierzęcia, w: Ludzie i zwierzęta, t. VI; Pongo, red. R. Chymkowski, A. Jaroszuk, Warszawa 2014; K. ŁuKASZEWICZ, Ogrody zoologiczne: wczoraj, dziś, jutro, Warszawa 1975; J. WARszA, Ludzkie zoo, „Krytyka Polityczna” 2010, nr 24-25; A. WieCzorkiewicz, Ludzki okaz na czterech scenach, „Czas Kultury” 2007, nr 6.

${ }^{14}$ Trzeba wyjaśnić, że jeszcze w XIX wieku (w literaturze przyrodniczej) mylnie zaliczano owady do robaków. Grzegorz Igliński omawia tę kwestię szczegółowo, odnosi się do ustaleń zoologii historycznej i współczesnej: „Naukowej nazwy Vermes (w randze gromady) użył po raz pierwszy szwedzki uczony Carl von Linné (Karol Linneusz) w poszerzanej z wydania na wydanie pracy Systema naturae... (pierwsza edycja - 1735; dziesiąta, uznawana za początek nomenklatury zoologicznej: vol. 1-2, 1758-1759). Z kolei francuski badacz, Jean-Baptiste de Lamarck, w pracy Histoire naturelle des animaux sans vertèbres (prwdr. t. 1-7, 1815-1822, pol. Historia naturalna zwierząt bezkręgowych) wprowadził jednostkę bezkręgowców, a w niej usytuował robaki (Vermes) i owady (Insecta).” - G. IGLIŃski, Z Mickiewiczowskiego bestiariusza. Owady i robaki w „Dziadach”, „Wiek XIX. Rocznik Towarzystwa Literackiego im. Adama Mickiewicza”, IX (LI): 2016, s. 8 (w przypisie podano źródła).

15 Skrzydła motyli zbudowane są z blaszek pokrytych barwnym pyłem. 
bo rozpoznanej przez człowieka rzeczywistości okrytej - z Norwidowskiej perspektywy - jakimś niezwykłym pięknem i tajemnicą życia.

Na wspomnianych wcześniej, masowo w wieku dziewiętnastym wytwarzanych obrazkach Aniołów Stróżów, owady nie są znaczące, ich status istnienia jest niski, podporządkowany człowiekowi, dla którego stanowią one jedynie igraszkę i zabawkę.WOstatniej z bajek natomiast owady wypowiadają się, ale w inny niż bajkowy sposób, ich przemowa przekracza bajkowe konwencje, został bowiem przesunięty przez Norwida punkt ciężkości, owady nie uosabiają tu cech ludzkich (tak jak w bajkach tradycyjnych lub epigramatycznych czy narracyjnych np. Ignacego Krasickiego), ale przede wszystkim odsłaniają swój niepowtarzalny status istnienia. Są samodzielnymi, integralnymi gatunkowo (analogicznie do człowieka) bytami. Norwid w bardzo interesujący literacko sposób przedstawia rzeczywistość, nie tyle bowiem z własnego (tzn. odautorskiego) stanowiska, ale z perspektywy owadów i innych zwierząt. Pozornie wydaje się, że jest to różny od ludzkiego pod względem np. ,jakościowym” świat, ale w Ostatniej z bajek ma on status analogiczny, każdy organizm uznać należy za wartościowy i na swój sposób niezwykły. Norwidowskie zwierzęta „posiadają” własne istnienie, którym nie mniej od człowieka są zafascynowane. Również perspektywa spojrzenia na osobę ludzką zmienia się, poznajemy ją i obserwujemy z punktu widzenia kilkumilimetrowej, kilkucentymetrowej istoty. Jest to oryginalny sposób obserwacji, wnoszącej w świat przedstawiony utworu liryzm będący kwintesencją stanowiska podmiotowego autora oraz uznania przez niego tajemnicy istnienia za wartość i prawdę o charakterze nadprzyrodzonym.

W bajkach np. ezopowych zwierzęta były nobilitowane lub np. ośmieszane ze względu na pewne cechy charakteru i wartości - ważne w świecie człowieka, np. uczciwość, miłość, dobroć, chytrość itp. Inaczej rzecz się ma w baśniach fabularnych: owady czy też drobne ptaki pełnią funkcje donatorów ${ }^{16}$. Najdrobniejsze zwierzęta odsłaniają spójność i przenikanie świata naturalnego i ponadnaturalnego, pomagają człowiekowi w walce ze złem, w życiowych wyborach, umożliwiają przedostanie się do innego, lepszego, doskonalszego świata. Jeśli człowiek jest dobry dla zwierząt, otrzymuje od nich pomoc, częstokroć ratują mu one życie, umożliwiają osiągnięcie celu (np. miłości „pod postacią” właściwej księżniczki lub magicznego atrybutu uzdrowienia: wody żywej czy innego skarbu). Dobry bohater otoczony jest opieką świata przyrody, on nie tylko nie zabija owadów, ale im pomaga z empatią i zrozumieniem, by nie powiedzieć z czułością. Zwierzęta mają

16 Zob. W. Propp, Morfologia bajki magicznej, przeł. P. Rojek, Kraków 2011, s. 40; E. WILCZYŃSKA, Symbolika pszczót i mrówek w polskiej kulturze ludowej, „Tekstura. Rocznik Filologiczno-Kulturoznawczy" 2013, t. 1. 
swój charakter i uczucia. Podkreślić w tym miejscu należy, że te aspekty życia zwierząt odkrywała współczesna Norwidowi (i wcześniejsza) historia naturalna (nie sposób przecenić w tym zakresie prac Karola Darwina i jego poprzedników).

W baśniach zwierzęta posiadają swoją własną świadomość, patrzą na człowieka z boku, widzą więcej. Mają dostęp do wiedzy, której człowiek nie potrafi zdobyć. Tak jest również w Ostatniej z bajek, stąd odpowiedź owadów na zaproszenie Anioła do wykonania wzniosłej tyrady na cześć nowonarodzonego dziecka. Nie zabrzmiał jednak hymn pochwalny opiewający wielkość i piękność człowieka, nie ma w nim naiwnego podziwu (niczym na wspomnianych obrazkach dzieci z Aniołem Stróżem), mimo że do tych przedstawień wypowiedź owadów nawiązuje:

„Piękny - piękny - piękny! jest człowiek-dziecię, i niebawem podziwiać go będziemy hasającego po łąkach - rumianego jak zorza - po pas w kwiatach, z rozwianymi złotymi włosy. Gdzie on ręką skinie, w której nieść będzie zdradną mgłę gazy, podchwyci motyle zbyt ufnie ssące kwiatki, podchwyci muszki złote, szklannoskrzydłe i tęczowe owadki... A potem, z uśmiechem powodzenia, poprzewierca im szpilkami karki i tak cały kapelusz i pudełka swoje przebitymi i przybitymi ustroi. One odkręcać się będą na kruszcowych palach i wspinać na wyprężane nogi z jękiem, którego nie dosłyszy tłuste ucho człowieka, gdy on wtedy po lowach, rzuciwszy się, jak byl, na posłanie, głęboko będzie spał, w pięknym odniechceniu tym nadobniejszy...” (DW VII, 243; podkr. E. Sz.-P.)

Człowiek „hasający” na obrazkach wywołuje skojarzenia idylliczne, ale idylla jest tylko iluzją piękna. Przy pomocy środków poetyckich Norwid oddaje charakter obserwacji prowadzonej jakby przez lupę, a więc w taki sposób, aby nie pominąc żadnego aspektu działania człowieka, odsłania obraz cierpienia owadów i bezwzględności osoby ludzkiej - łowcy, z tłustym uchem, który zasypia po spustoszeniu, którego dokonał. Poeta dzięki takiemu sposobowi prowadzenia narracji osiąga niezwykły efekt podwójnego powiększenia: z jednej strony - owadów, z drugiej - człowieka (jego pracy w insektarium). Uzyskuje go dzięki temu, że owady (szerzej zwierzęta) otrzymały w utworze status bohaterów.

\section{WOBEC STWORZEŃ. O INSEKTARIUM}

Piękno (w myśli Norwidowskiej) nie może zamknąć się w idyllicznych obrazkach, objawia się w relacji i to nie tylko z drugim człowiekiem (choć u Norwida relacja człowiek - człowiek nie jest przedstawiana jako doskonała), ale także w relacji człowieka wobec wszystkich istot żywych i wobec każdego istnienia-stworzenia z osobna, wobec istnienia jako takiego. Relację człowieka z inną osobą oraz innym istnieniem-stworzeniem wymienić należy na pierwszym miej- 
scu, ponieważ w Norwidowskim świecie wartości jest to miarą ewentualnej relacji człowieka z Bogiem. Obraz poetycki owadów wbijanych na pal, przebijanych w entomologicznym prosektorium (bo w coś takiego przekształca się przestrzeń łąki) po to, aby zrobić ozdobne pudełka czy gabloty i pseudonaukowe eksponaty, które pochwali profesor, posiada silne zabarwienie emocjonalne, zwłaszcza w obliczu dziewiętnastowiecznej mody na preparowanie motyli i innych owadów. W Ostatniej z bajek czytamy, że po takim polowaniu człowiek smacznie zaśnie:

„I przyjdzie matka, pojrzy, zachwyci się - miękkim palcem odgarnie jemu włosy z powiek - chustą wonną obetrze mu czoło. Profesor przebudzonego wychwalać będzie, iż wdzięcznych tyle trudów poniósł - - ale on się nic $\mathrm{z}$ tego ani się nikt $\mathrm{z}$ tego nic nie nauczy!...” (DW VII, 243)

Powszechna akceptacja postawy człowieka wobec stworzeń daje do myślenia. Anioł Stróż z wyobraźni zbiorowej uwiecznionej w kolorowych obrazkach, wizerunek matki i profesora (zapewne historii naturalnej) - dają przyzwolenie na ten pogrom w świecie przyrody. Padły w utworze ważne, odautorskie słowa, że z tychże spreparowanych, nabitych na szpilki owadów umieszczonych w pudełkach czy gablotach lub z fantazją na kapeluszach, nikt nic się nie nauczy, stąd ostrzeżenie dla świata zwierzęcego: „Wystrzegajcie się jego [mowa o człowieku], jakkolwiek jest piękny i wzniosły!"

Nie w słowach Anioła, ale w słowach owadów brzmi odautorski głos sprzeciwu wobec, nie tyle człowieka jako takiego - taka teza nie byłaby zgodna z całym opus magnum Norwida (przecież człowiek jest stworzeniem, istotą żywą wywodzącą się od Boga), ile wobec zerwanych przez niego więzi z innymi stworzeniami, które wcale nie są gorsze czy mniej doskonałe od człowieka (wszystko co Bóg uczynił było dobre i piękne, cieszyło Boga: owady oraz inne istoty żywe cieszyły go zatem nie mniej od człowieka). Kolejne partie Ostatniej z bajek rozwijają obrazy bezrefleksyjnego i bezmyślnego okrucieństwa człowieka: odcinanie skrzydeł ptakom na ozdobne piórka do kapeluszy, zabieranie pożywienia zgromadzonego na zimę przez wiewiórki, łowienie ryb na robaczą przynętę - przebijanie robaka hakiem, oprawianie skóry wołu, zabijanie w celach przemysłowych ${ }^{17}$ :

On [człowiek - E. Sz.-P.] rozwiesi w jatkach białe i tuczne trupy i bawić się będzie wyrzezywaniem we wzory skóry i mięsa, i umai je liśćmi zielonymi. Tamtędy potem pędzić będzie na rzeź sprzedane i z obłędem patrzące bydło.

${ }^{17} \mathrm{Na}$ ten aspekt wskazywała Magdalena RUDKowsKa (Ostatnie z bajek. Romantyczna iluzja), wcześniej Janina Abramowska (Pisarze w zwierzyńcu) która napisała: ,zamiarem autora Ostatniej z bajek jest pokazanie ludzkiego egoizmu i krzywdy zwierząt” (tamże, s. 41). 
Albowiem jego całą rzeczą jest i było, po wszystkie czasy, od rana do nocy, tym się zaprzątać jednym, ażeby wszystko podstępem ująć, zamordować, złupić, i zjeść, i zjeść... i co tylko można, na siebie wdziać, a wszystko sobie przysądzić. (DW VII, 245)

Ta proza poetycka z całą siłą oddaje męczeństwo zwierząt. Wątek w badaniach podjęła Magdalena Rudkowska, która napisała:

Ostatnia z bajek jest demonstracją krzywdy, zbrodni, za którą odpowiada człowiek wobec zwierząt, a jednocześnie głębokiej rany, którą zadał sam sobie, odrywając się od pierwotnej harmonii i tajemnicy istnienia obok nich ${ }^{18}$.

Norwid nie tyle atakuje osobę ludzką, ile wyraża utraconą przez nią wrażliwość, brak samoświadomości, czyli prawdy o sobie samym jako istocie żywej, stworzonej pośród innych istot (tak jak on) stworzonych, a zatem współistniejących. Dobitnie wyraża tę myśl sformułowanie Norwida o „twardości serca człowieka”.

„Rozwijanie piękności własnej” - te słowa poety - byłyby wielką szansą dla człowieka i wspólnoty istot żywych, od których de facto zależne jest jego życie. Tak brzmi remedium zapisane przez poetę na twardość serca człowieka. To nie wykrzykiwana przez Anioła, (który właśnie pojawił się na ziemi) tyrada, że człowiek jest piękny - ma sens w świetle utworu, brzmi bowiem jak slogan, wytarta formuła, nie o taką piękność chodzi jak na obrazkach przedstawiających dzieci z Aniołem Stróżem, czy dziecka niesionego do chrztu lub śpiącego w kołysce. „Rozwijanie piękności własnej” związane jest z pracą, wysiłkiem, trudem rozumienia, z samoświadomością, z uważną lekturą księgi życia, z czułością i szacunkiem wobec każdego istnienia. Piórka z uciętych skrzydeł ptasich przyczepione do kapelusza to tylko dowód „odzierania cudzej piękności i brania na siebie”, a nie „,rozwijania piękności własnej”. Określenia „cudza piękność” - to znak, że ptaki również obdarzone są pięknością, którą człowiek zabiera, ale to zabrane piękno nie czyni go pięknym, ujawnia tylko jego ,twarde serce” w całej głębi znaczeń ewangelicznych (szerzej biblijnych) ${ }^{19}$.

\section{CYPRIAN NORWID - ZYGMUNT KRASIŃSKI - OWADY POETÓW, CZYLI W STRONĘ KONCEPCJI PIĘKNOŚCI}

Skąd u Norwida tak niezwykły i oryginalny obraz owadów i człowieka? Jednym ze źródeł z pewnością jest Nie-Boska Komedia Zygmunta Krasińskiego.

\footnotetext{
18 RudKowsKa, s. 369.

${ }^{19}$ Jest to bezpośrednie nawiązanie do biblijnej formuły, która pojawia się w wielu miejscach Biblii: „Nie zatwardzajcie serc”- Mk 3, 1-6.
} 
W opisie Orcia pojawia się analogiczny obraz owadów, który musiał wpłynąć na wyobraźnię Norwida, nie chodzi tu o tożsamość znaczeń, ale o źródło dla wyobraźni poetyckiej. Przytoczę obraz z Nie-Boskiej Komedii:

Czemu o dziecię, nie hasasz na kiju, nie bawisz się lalką, much nie mordujesz, nie wbijasz na pal motyli, nie tarzasz się po trawnikach, nie kradniesz łakoci, nie oblewasz łzami wszystkich liter od A do Z? - Królu much i motyli, przyjacielu poliszynela, czarcie maleńki, czemuś tak podobny do aniołka? - Co znaczą twoje błękitne oczy, pochylone, choć żywe, pełne wspomnień, choć ledwo kilka wiosen przeszło ci nad głową? - Skąd czoło opierasz na rączkach białych i zdajesz się marzyć, a jako kwiat obarczony rosą, tak skronia twoje obarczone myślami? ${ }^{20}$

Orcio - mały bohater Nie-Boskiej Komedii oraz przywołany powyżej urywek prozy poetyckiej dramatu musiały zrobić na Norwidzie ogromne wrażenie. W przytoczonym fragmencie polowanie na owady, przebijanie ich szpilkami zrównane jest z innymi czynnościami „,charakterystycznymi” dla dziecka takich jak: bawienie się lalką, wykradanie łakoci, tarzanie się po trawniku czy „oblewanie łzami wszystkich liter”. Obraz ten musiał być mocno zakorzeniony w obyczajowości epoki. Wrażliwość Krasińskiego jako poety pozwoliła mu na wydobycie tych obrazów z życia dzieci, a tym samym zachowań powszechnie akceptowanych, nawet tych, w których człowiek - „król much i motyli” zgodnie z dziewiętnastowieczną modą łowi je w siatkę z gazy i robi preparaty przyrodnicze lub okazy-obrazy. Krasiński jak nikt to rozumiał, zmuszany do polowań, wychowywany przez ojca generała zderzył się z oczekiwaniami dorosłych, z kultywowanym w wielu familiach obrazem chłopca (małego myśliwego ${ }^{21}$ ), a później mężczyzny, z obrazem człowieka, który może (ma prawo - z racji swego statusu społecznego i biologicznego) z przynależną mu siłą, odnosić się do innych istot (podległych mu przecież). Mówimy o świecie przyrody, ale nie możemy zapominać, że to czasy pańszczyzny i skomplikowanych, pełnych napięć stosunków społecznych (to osobny problem, ale ważny z perspektywy rozpatrywanej kwestii).

Owady Krasińskiego i Norwida składają się na znacznie głębszą dyskusję, jaka toczy się w obu utworach, dyskusję nad statusem człowieka oraz istotą ,piękności”. Na tym bowiem poziomie toczy się swego rodzaju „poetycka” rozmowa

20 Z. KrasińsKi, Nie-Boska Komedia, w tomie: Dzieła literackie, wybrał, notami i uwagami opatrzył P. Hertz, Warszawa 1973, t. I, s. 347.

${ }^{21}$ Zob. L. S. [L. Siemieński], Przewodnik myśliwca, Leszno i Gniezno 1848, s. 3. Zagadnienie myślistwa podjęła m.in. B. MYTYCH-ForaJTER, Poetyka i łowy. O idei dawnego polowania w literaturze polskiej XIX wieku, Katowice 2004. Wątek ten zaakcentowała M. RuDKowsKA, Ostatnie z bajek. Romantyczna iluzja. 
Norwida z Krasińskim (temu służyło owo,,zapożyczenie” obrazu, aluzja do NieBoskiej Komedii w Ostatniej z bajek).

Ideę piękności wyrażoną przez Krasińskiego najpełniej odsłania fraza z NieBoskiej Komedii: „Przez ciebie płynie strumień piękności, ale ty nie jesteś pięknością". Nie odnosi się ona tylko do hrabiego Henryka czy też do pozostałych postaci dramatu, ale do człowieka jako takiego. Myślenie Krasińskiego o stosunku: człowiek - piękno przenika jakiś rodzaj pesymizmu. Osoba ludzka nie jest „pięknością", jej żywioł jest wobec niej zewnętrzny (pochodzący od Boga). Doświadczenie piękna jest możliwe, ale owo piękno nie przynależy człowiekowi z istoty zjawisk (on nie jest pięknością).

Odpowiedzią Norwida w Ostatniej z bajek byłaby spoczywająca na człowieku powinność, którą najpełniej wyraża wezwanie, aby: „rozwijać piękność własną". Są to dwa różne stanowiska, nie sposób ich omówić w tym miejscu. Norwidowskie „rozwijanie piękności własnej”, to przesiąknięte nadzieją słowa, że w życiu można do piękności dążyć, dokonywać świadomych wyborów, tym samym kształtować rzeczywistość i jakość istnienia. Nie jest to wizja katastroficzna, nie ma w tym predestynacji czy jakiegokolwiek ograniczenia, uwięzienia możliwości człowieka, ale jednocześnie objawia się konieczność wynikająca z istoty rzeczy, z natury głębokiej człowieka i z sensu życia - dodajmy - każdego życia (bytu), a więc nie tylko ludzkiego. „Rozwijając piękność własną” człowiek może pozbywać się zatwardziałości serca.

Norwid w Ostatniej z bajek nie jest poetą-obserwatorem. Obserwacja bowiem zamieniła się w obecność, stąd wyrazistość podmiotu (autora), który pomimo weryzmu nie jest narratorem, ale osobowością liryczną. Właśnie owa obecność, wyrastająca z głębokiej świadomości i wiedzy pozwala mu odsłonić prawdę na temat bytu i człowieka. Obecność staje się u Norwida jednocześnie namysłem nad naturą rzeczy, naturą istnienia jako takiego. Obserwacja umożliwia zajęcie stanowiska wobec osób i zdarzeń - podmiot pozostaje niejako na zewnątrz opisywanej rzeczywistości, natomiast obecność staje się możliwa wtedy, gdy podmiot przenika do wewnątrz i staje się częścią rzeczywistości, bierze za nią odpowiedzialność i z tej perspektywy z przenikliwością doświadcza rozumienia istoty rzeczy. Ostatnia z bajek stała się wyrazem takiej zaangażowanej obecności poety.

\section{PRZEMIANY}

W tradycyjnych baśniach prawdziwy bohater przechodzi metamorfozę - ona właśnie jest istotą fabuły. W Ostatniej z bajek dochodzi do dwóch takich przemian. Jedna wydaje się nad wyraz zaskakująca: jedynie w baśni możliwa, jest to 
przemiana zachodząca w postaci Anioła, który - przyleciawszy z niebios - słuchając skarg owadów zaczyna rozumieć rzeczywistość, a tym samym bezmiar cierpienia stworzeń na ziemi. Dowodem przemiany jest trzecia część utworu. Anioł w ogromnym wysiłku zmierza do Libanu (do Ziemi Świętej), w jakim celu? Określa się to jako „pilny bez-interes”. Poszukuje osób, które nie skrzywdziły i nie krzywdzą innych stworzeń. Znajduje takich ludzi - baśń będzie miała szczęśliwe zakończenie. To pustelnicy modlący się w wykutej w skale grocie, przed ołtarzem. Anioł czuje, że dotarł do celu, odnalazł to, czego szukał:

Radowały się wyraźnie oczy jego widokiem aby dwóch ludzi, na których żywocie, mieniu i obyczaju nie było żadnej skazy naznaczonej gwałtem lub krzywdą jakąkolwiek bliźniego, ludzkości i stworzenia!... to ku temu więc lecial tak skoro z daleka... To ku temu więc taką trzeba było zadawać sobie podróż oddaloną i poszukiwanie przedsiębrać tak usilne! (DW VII, 248; podkr. E. Sz.-P.)

Anioł zatem - wbrew „zasadom”- (opuścił powierzone mu dziecko), przebył długą drogę w poszukiwaniu źródła wiedzy i znalazł dwóch pustelników, którzy nie skrzywdzili żadnego ze stworzeń. Trwali w modlitwie, w żywym kontakcie z Bogiem. Grota, w której odbywa się nabożeństwo jest przestrzenią poznania (wtajemniczenia), które dzięki postawie kontemplatywnej dokonuje się w głębi ich serc. Nie było jednak nikogo, kto by poza nimi uczestniczył w tej modlitwie, oprócz dwóch lwów (które - dodajmy - pomimo swej drapieżnej natury - nigdy nie zabijają dla zabawy, a żadne stworzenie nie jest dla nich zabawką, w świetle Ostatniej z bajek tylko człowiek z innych istot potrafi czynić zabawkę). Dla fabuły utworu znamienne wydaje się, że to nie człowiek-dziecię przechodzi metamorfozę (będącą podstawą baśni), ale doświadcza jej Anioł, który znajduje w świecie dobro i niewinność, ale nie w małym dziecięciu - na razie tylko niewinnym - z racji swej bezbronności. „Piękność” bowiem rodzi się w spotkaniu człowieka z Bogiem, w potrzebie Boga i zrozumieniu istoty życia, w modlitwie i kontemplacji, która pozwala człowiekowi odnaleźć w świecie właściwy ład i własne miejsce pośród innych istot, które tak jak on posiadają życie pochodzące tego samego dawcy.

Ostatnia z bajek to późne dzieło Norwida - trzeba to podkreślić, by zrozumieć, że utwór odsłania drugą (oprócz anielskiej) przemianę, która dokonała się niejako ,poza fabułą utworu”, owa przemiana musiała zajść także w poecie, w wyniku głębokiego zrozumienia istoty aktu stwórczego. Najpełniej można to wyrazić pisząc, że owady zaprowadziły Norwida-poetę, a jednocześnie głównego „bohatera” Ostatniej z bajek tam, gdzie motyl jedwabnik z mistycznego liryku Snuć miłość. Przypowieść Norwida ma swoją głęboką puentę. Tradycyjna baśń kończy się dobrze. Norwid nie pozostawił za sobą nadziei - to ważne w aksjologii tego poety, 
ważne dla sposobu, w jaki patrzył na istotę ludzką, dlatego w Ostatniej z bajek cytuje on frazę z Biblii, ale nie tę, którą człowiek tak szybko przeinaczył i opatrznie zrozumiał (tzn. „Czyńcie sobie ziemię poddaną”), ale fragment Księgi Ozeasza, w której Bóg mówi o przymierzu z każdym zwierzęciem polnym i z ptactwem powietrznym, aby te mogły ,spać bezpiecznie”. Przymierze Boga z wszystkimi istotami, które posiadają życie, a więc najwyższą wartość, najpełniej wyraża miejsce na ziemi chociażby owadów: much i motyli. A zatem nie tylko z człowiekiem zawarł Bóg przymierze. Jedynie w sposób nadprzyrodzony można zrozumieć przemianę Norwida, zwłaszcza teorię o mowie zwierząt jako glosolalii, o której pisał m.in. w Fabulizmie Darwina.

\section{BIBLIOGRAFIA}

Abramowska J., Darwin, Ezop i Aniot, w: Nie tylko o Norwidzie, red. J. Czarnomorska, Z. Przychodniak, K. Trybuś, Poznań 1997.

Abramowska J., Pisarze w zwierzyńcu, Poznań 2010.

Baranowska M., Anioł [hasło], w: Stownik literatury polskiej XIX wieku, red. J. Bachórz, A. Kowalczykowa, Wrocław 2009, s. 26-28.

DuchińsKa S., Kronika Paryzka, „Biblioteka Warszawska” 1864, t. 3.

Feliksiak E., Darwin Norwida, „Teksty” 1972, nr 4.

GoMULICKI J.W., Metryki i objaśnienia: „, Ostatnia z bajek”, PW, t. VII, cz. II.

HALKIEwICZ-SoJAK G., Wobec tajemnicy i prawdy. O Norwidowskich obrazach „całości”, Toruń 1998.

IGLIŃsKi G., Z Mickiewiczowskiego bestiariusza. Owady i robaki w „Dziadach”, „Wiek XIX. Rocznik Towarzystwa Literackiego im. Adama Mickiewicza”, R. IX (LI) 2016.

KluszczyŃska M., Ogród zoologiczny jako miejsce konstruowania Zwierzęcia, w: Ludzie $i$ zwierzęta, t. VI; Pongo, red. R. Chymkowski, A. Jaroszuk, Warszawa 2014.

KozıoŁek R., Kompleks Darwina, „Teksty Drugie” 2011, z. 3.

Księga o Aniołach, red. H. Oleschko, Kraków 2002.

LeHr-Splawiński P., Darwin - Narwid - Norwid, w: Dziewiętnastowieczność, red. E. Czaplejewicz, W. Grajewski, Wrocław-Warszawa 1988.

ŁuKASZEWICz K., Ogrody zoologiczne: wczoraj, dziś, jutro, Warszawa 1975.

Merdas A. RSCJ, Ocalony wieniec, Warszawa 1995.

Mytych-Forajter B., Poetyka i łowy. O idei dawnego polowania w literaturze polskiej XIX wieku, Katowice 2004.

Otsason R., Aniot [hasło], w: Powszechna Encyklopedia Filozofii, Lublin 2000, t. 1, s. 234-235.

Pamiętniki Anioła Stróża przez księdza Chardou, Pelplin 1872.

Propp W.A., Morfologia bajki magicznej, przeł. P. Rojek, Kraków 2011.

Rejchman B., Teoria Darwina w stosunku do nauki życia, Warszawa 1882.

RudKowska M., Ostatnie z bajek. Romantyczna iluzja wspólnoty ludzko-zwierzęcej i jej rozpad, „Wiek XIX. Rocznik Towarzystwa Literackiego im. Adama Mickiewicza”, 2014. 
Siemieński L., Przewodnik myśliwca, Leszno i Gniezno 1848.

Stefanowska Z., Próba zdrowego rozumu. Studia o Mickiewiczu, Warszawa 1976.

Szagun D., Aniot i anielskość w romantyzmie na podstawie poezji Kornela Ujejskiego i Cypriana Norwida, w: Anioł w literaturze $i$ w kulturze, red. J. Ługowska, J. Skawiński, Wrocław 2004, t. 1.

Szczeglacka-Pawıowska E., Romantyzm ,, brulionowy”, Warszawa 2015.

WaksmundzKa I., Anioł u Norwida, „Colloquia Litteraria” 2017, nr 1.

Warsza J., Ludzkie zoo, „Krytyka Polityczna” 2010, nr 24-25.

WieCzORKIEWICz A., Ludzki okaz na czterech scenach, „Czas Kultury” 2007, nr 6.

WiLCzYŃSKa E., Symbolika pszczół i mrówek w polskiej kulturze ludowej, „Tekstura. Rocznik Filologiczno-Kulturoznawczy" 2013, t. 1.

\title{
OWADY NORWIDA \\ OSTATNIA Z BAJEK, CZYLI O PIĘKNOŚCI ISTNIENIA
}

Streszczenie

Artykuł jest studium interpretacyjnym, w którym Ewa Szczeglacka-Pawłowska omawia Ostatnia z bajek jako dzieło późne poety. Punktem wyjścia dla szczegółowych rozpoznań o charakterze interpretacyjnym są pytania o obraz i znaczenie przywołanych w utworze owadów, a także o wymiar liryczny bajkowej przypowieści Norwida. Autorka odsłania wpływ entomologii romantycznej, a także konkretnych fragmentów Nie-Boskiej Komedii Zygmunta Krasińskiego na sposób przedstawiania przez Norwida obrazu świata jako współistnienia człowieka z różnymi stworzeniami i bolesnej utraty więzi z innymi istotami. Liryzm i podmiotowość w Ostatniej z bajek mają swoje źródło w kontemplatywnym stosunku autora utworu wobec szeroko pojętej rzeczywistości, stąd ważne pytania postawione w artykule - o wymiar „piękności” istnienia, które to pytania określają główny temat bajki lirycznej Norwida.

Słowa kluczowe: Cyprian Norwid; Ostatnia z bajek; entomologia romantyczna; owady w literaturze; anioł; rysunki Cypriana Norwida; Norwidowska koncepcja piękna.

\section{NORWID'S INSECTS. \\ “OSTATNIA Z BAJEK”, OR ON THE BEAUTY OF EXISTENCE}

\begin{abstract}
This article offers an interpretation of one of Norwid's late works: Ostatnia z bajek [The Last of the Fairy Tales].The starting point for this specific reading is the question regarding the image and meaning of the insects invoked in this workas well as the lyrical dimension of this fairy-tale-like fable. The article reveals the impact of Romantic entomology as well as specific passages from Zygmunt Krasiński's Nie-Boska Komedia [The Undivine Comedy] on the ways in which Norwid develops an image of the world as a place where humans coexist with other beings and experience the painful loss of the bond with these fellow creatures. Lyricism and
\end{abstract}


subjectivity in "Ostatnia z bajek" are rooted in the author's contemplative attitude towards broadly understood reality. This raises the question posed in the title - one regarding the beautyof existence - which defines the the main topic of Norwid's lyrical fairy tale.

Translated by Grzegorz Czemiel

Key words: Cyprian Norwid; Ostatnia z bajek [The Last of the Fairy Tales]; Romantic entomology; insects in literature; angel; Norwid's drawings; Norwid's idea of beauty.

Ewa Szczeglacka-PawıowsKa - dr hab., prof. uczelni, Uniwersytet Kardynała Stefana Wyszyńskiego w Warszawie. Autorka monografii: Romantyczny homo legens. Zygmunt Krasiński jako czytelnik polskich poetów, Warszawa 2003, Romantyzm „, brulionowy”, Warszawa 2015, Współredaktorka książek: Zygmunt Krasiński. Pytania o twórczość, Warszawa 2005; Juliusz Słowacki - interpretacje i reinterpretacje, Warszawa 2011, autorka wielu artykułów naukowych poświęconych twórczości późnej, brulionowej poetów romantycznych. Zainteresowania naukowe: historia literatury polskiej XIX wieku (romantyzm), w szczególności liryka i twórczość późna poetów oraz dokumenty prywatne (korespondencja, raptularze, pamiętniki), utwory nieopublikowane za życie autorów (romantyzm brulionowy), historia poezji. Adres: e.szczeglacka@uksw.edu.pl 